\title{
Bioerosion by microbial euendoliths in benthic foraminifera from heavy metal-polluted coastal environments of Portovesme (south-western Sardinia, Italy)
}

\author{
A. Cherchi ${ }^{1}$, C. Buosi ${ }^{1}$, P. Zuddas ${ }^{2}$, and G. De Giudici ${ }^{1}$ \\ ${ }^{1}$ Dipartimento di Scienze Chimiche e Geologiche, Università degli Studi di Cagliari, Via Trentino 51, 09127 Cagliari, Italy \\ ${ }^{2}$ Institut des Sciences de la Terre de Paris, Université Pierre et Marie Curie, Paris-Sorbonne, place Jussieu 4, \\ 75252 Paris Cédex05, France
}

Correspondence to: A. Cherchi (acherchi@unica.it)

Received: 26 June 2012 - Published in Biogeosciences Discuss.: 20 August 2012

Revised: 19 October 2012 - Accepted: 28 October 2012 - Published: 20 November 2012

\begin{abstract}
A monitoring survey of the coastal area facing the industrial area of Portoscuso-Portovesme (south-western Sardinia, Italy) revealed intense bioerosional processes. Benthic foraminifera collected at the same depth (about $2 \mathrm{~m}$ ) but at different distances from the pollution source show extensive microbial infestation, anomalous $\mathrm{Mg} / \mathrm{Ca}$ molar ratios and high levels of heavy metals in the shell associated with a decrease in foraminifera richness, population density and biodiversity with the presence of morphologically abnormal specimens. We found that carbonate dissolution induced by euendoliths is selective, depending on the Mg content and morpho-structural types of foraminiferal taxa. This study provides evidences for a connection between heavy metal dispersion, decrease in $\mathrm{pH}$ of the sea-water and bioerosional processes on foraminifera.
\end{abstract}

\section{Introduction}

Boring microflora, constituted by cyanobacteria, algae and fungi may colonise carbonate substrates of both dead and living tissues of carbonate organisms (Tribollet, 2008). Boring is evident in carbonate organisms from the Mesoproterozoic (Zhang and Golubic, 1987) to the present day as a consequence of environmental conditions (Hallock, 2005). Microbial euendoliths have been described in coral reefs, molluscs, thalli of red algae (e.g. Golubic et al., 1975; Perkins and Tsentas, 1976; Budd and Perkins, 1980; Glaub, 1994, 2004; Chazottes et al., 1995, 2002; Le Campion-Alsumard et al., 1995; Vogel et al., 2000; Tribollet and Payri, 2001; Ghirardelli, 2002; Golubic and Schneider, 2003; Tribollet and Golubic, 2005; Tribollet, 2008; Tribollet et al., 2009), in coastal eroded limestones (Schneider and Torunski, 1983; Radtke et al., 1996), in carbonate grains (Tudhope and Risk, 1985; Al-Thukair and Golubic, 1991; Al-Thukair, 1999), as well in oil polluted marine environments (Campbell, 1983; Al-Thukair, 2002; Al-Thukair et al. 2007) and heavy-metal polluted lagoons (Succi et al., 2010).

Microborings are major agents of bioerosion dissolving large quantities of calcium carbonate with a potential in buffering seawater $\mathrm{pH}$, which leads to new questions on the effects of environmental factors such as eutrophication and atmospheric $\mathrm{CO}_{2}$ increase on ocean composition evolution (Tribollet, 2008). On the other hand, present-day geochemical models predict that the saturation state of surface ocean water with respect to carbonate minerals should decline during the twenty-first century. As a result calcareous organisms may have difficulties to calcify, leading to production of weaker skeletons and greater vulnerability to bioerosion. Organisms utilizing the more soluble form of $\mathrm{CaCO}_{3}$ (aragonite or high-Mg calcite) would be more adversely affected by elevated $p \mathrm{CO}_{2}$ than those utilizing the less soluble low-Mg calcite (Morse, 1983; Morse et al., 2007).

Investigations on microborings in foraminifera are documented in a small body of literature (Perkins and Halsey, 1971; Alexanderson, 1972; Golubic et al., 1984; Peebles and Lewis, 1988; Shroba, 1993; Freiwald, 1995; Perry, 1998; Nielsen et al., 2003; Crevison and Hallock, 2007) and open a 
debate that needs to be developed. Benthic foraminifera secreting calcium carbonate shells are considered to be very sensitive to the environmental conditions of the host sea water (e.g. Boyle, 1981; Wefer et al., 1999; Lea, 2004; Munsel et al., 2010). Species distribution and population densities of foraminifera are in fact used for pollution monitoring (Alve, 1991, 1995; Yanko et al., 1994, 1999; Debenay et al., 2001, 2005; Coccioni et al., 2003, 2005; Armynot du Châtelet et al., 2004; Cherchi et al., 2009; Frontalini et al., 2009; Romano et al., 2009; Frontalini and Coccioni, 2011; Denoyelle et al., 2012; Foster et al., 2012). Hallock (2000a, b) suggested that climatic change including increasing atmospheric $\mathrm{CO}_{2}$ and stratospheric ozone depletion may be the cause of borings developing on carbonate organisms. Indeed, effects of elevated $p \mathrm{CO}_{2}$ on coral reef bio-erosion have been observed and explained through a mechanism of carbonate dissolution in a more acidic ocean (Tribollet et al., 2009). The activity of boring microflora can result in differential bioerosion depending on both $p \mathrm{CO}_{2}$ partial pressure (Tribollet et al., 2009) and $\mathrm{Mg} / \mathrm{Ca}$ ratio of the foraminifera tests (Peebles and Lewis, 1988; Bentov and Erez, 2005).

The aim of our study is to investigate the effects of microbioerosion on benthic foraminifera and trace element dynamics in a known coastal industrial site polluted by heavy metals and industrial release of $\mathrm{CO}_{2}$ (Schintu and Degetto, 1999). Field studies in the coastal area neighbouring the industrial complex of Portoscuso-Portovesme (Southern Sardinia, Italy, Fig. 1) show that the presence of high levels of heavy metals results in an increase in bioerosional processes on foraminifera by boring microflora. The stressed environmental conditions in this area have been highlighted in Cherchi et al. (2009) through an analysis of the biotic indices of foraminifera tests (Dominance, Shannon-Weaver, Simpson, Evenness, Menhinick, Margalef, Equitability, Fisher$\alpha$, Berger-Parker and Q-mode Cluster Analyses - Ward Method) in this polluted environment.

\section{Environmental setting}

The study area is characterised by a relatively confined shallow shelf, which slopes gently to deeper water environments (Fig. 1). Bottom sediments comprise sandy submarine beach (Pleistocene-Holocene in age), while Oligo-Miocene calcalkaline volcanics crop out north of the sampling area. This south-western coast of Sardinia has been under major anthropogenic pressure since the 1960s, when the PortoscusoPortovesme district began to develop and expand its activities. The Portovesme Harbour, built in 1870 to ship ores (zinc blend, galena and pyrite) from the historical mines of the Sulcis-Iglesiente district, received major inputs from industrial discharge until a few decades ago. Chemical analysis of marine sediments from 4 cores collected in the harbour of Portovesme facing the industrial complex revealed in the upper $2 \mathrm{~cm}$ high concentrations of $\mathrm{Hg}$ (up to $50 \mathrm{mg} \mathrm{kg}^{-1}$ ), $\mathrm{Cd}$ (up to $120 \mathrm{mg} \mathrm{kg}^{-1}$ ), $\mathrm{Pb}$ (up to $20 \mathrm{mg} \mathrm{kg}^{-1}$ ) and $\mathrm{Zn}$ (up

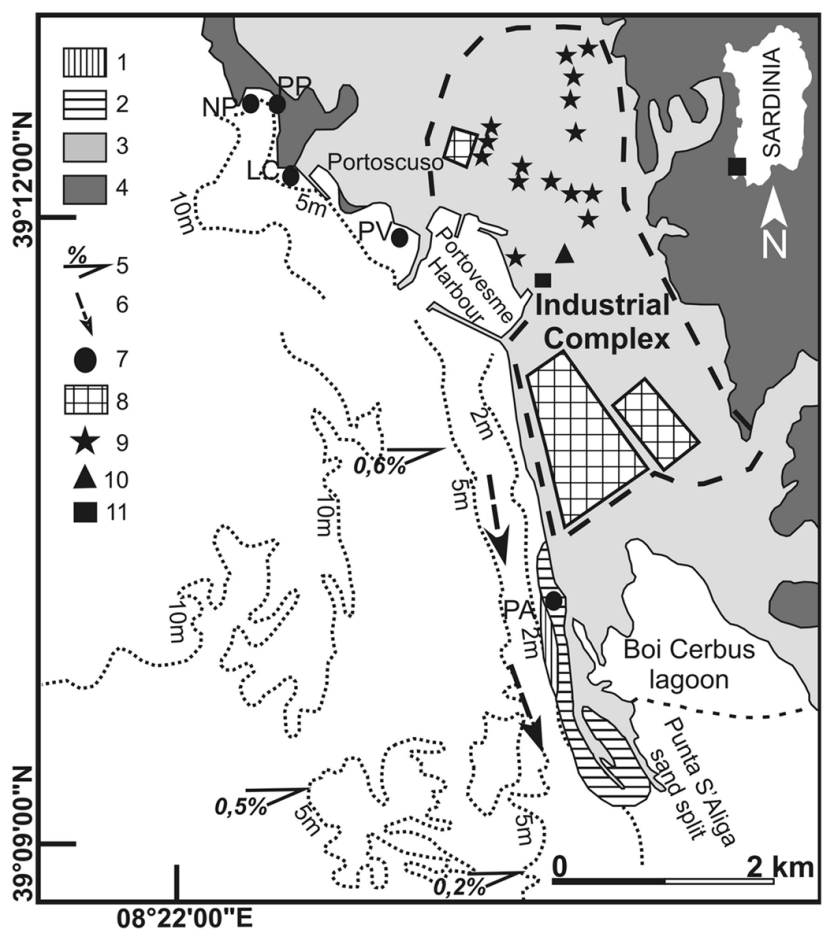

Fig. 1. Study area, location of sampling stations (Porto Pauleddu - NP, Porto Paglietto - PP, La Caletta - LC, Portovesme - PV, Punta S'Aliga - PA) and industrial complex of Portoscuso (SW Sardinia). 1. Submarine beach (grain size mean 0.13-0.1 mm). 2. Submarine beach (grain size mean $0.18-2.00 \mathrm{~mm}$ ). 3. Alluvial deposits (Pleistocene-Holocene). 4. Volcanics (Oligo-Miocene). 5. Seabottom slope (\%) from shoreline to $5 \mathrm{~m}$ isobath. 6. Longshore drift. 7. Sampling stations. 8. Red mud dumps. 9. Chimneys. 10. Lead-zinc smelter. 11. Electric power plant (1, 2, 5, 6 from Di Gregorio et al., 1996; modified).

to $70 \mathrm{mg} \mathrm{kg}^{-1}$ ) were found. Metal concentration decreases with an increase in distance between the sampling station and the industrial effluent discharge point (Schintu and Degetto, 1999). This large industrial development had a considerable environmental impact, such that this industrial district has been declared an environmental hazard (D.P.C.M. - Prime Ministerial decree, 23 April 1993) because of the several "danger centres" recognised (Agenzia Regionale per la Protezione dell' ambiente della Sardegna - ARPAS, 2007).

Emissions into the atmosphere and all of the surrounding environments have been estimated annually at 65000 tons of $\mathrm{SO}_{x}, 4000$ tons of dust, 10 tons of $\mathrm{Pb}$ and 100 tons of $\mathrm{Fe}$ (Gazzetta Ufficiale Italiana, 1993). The large electric power stations and the numerous chimneys produce also significant amounts of $\mathrm{CO}_{2}$ (Schintu and Degetto, 1999; Bettini and Zanin, 2002). The industrial complex, developed on an alluvial plain near the sea, includes factories producing aluminium from bauxite and a lead-zinc smelter producing $\mathrm{Pb}$, $\mathrm{Zn}, \mathrm{Cd}, \mathrm{H}_{2} \mathrm{SO}_{4}$ and $\mathrm{Hg}$ from $\mathrm{Pb}$ and $\mathrm{Zn}$ mixed sulphides. A 


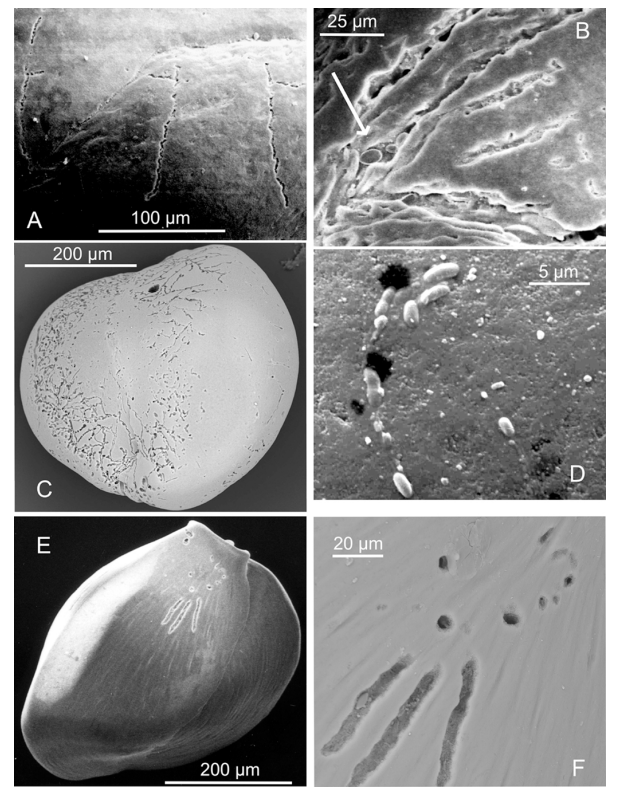

Fig. 2. SEM images of surface bioerosion of porcelanaceous imperforate foraminifera. (A) Tubular wavy tunnels parallel to substrate in Pseudotriloculina rotunda (d'Orbigny) exhibiting a rectangular ramification belonging to Orthogonum (cf. Form 1 in Wisshak et al., 2005). (B) Invasive infestation of microborings concentrated along the sutures of the chamber walls producing large galleries frequently occupied by pennate diatoms (arrow) in Quinqueloculina sp. (C) Dense boring pattern made up of fungal filaments developed in Triloculina cf. marioni Schlumberger. (D) Colony of rod-shaped cryptoendolithic bacteria made into previous holes of larger diameter in the wall surface of Adelosina sp. (E) Tubular borings, 4-5 $\mu \mathrm{m}$ in diameter, running parallel to surface of the test and penetrating into the wall of Quinqueloculina ungeriana d'Orbigny. (F) Enlargement of $(\mathbf{E})$.

large dump of red muds (seawater-neutralised bauxite refinery residues) is located near the coast.

\section{Material and methods}

Sixteen surface sediment samples, coming from an area about $12 \mathrm{~km}^{2}$, were collected in the inner shelf facing the industrial complex of Portoscuso-Portovesme where seawater is less than $2 \mathrm{~m}$ deep. Four stations (PP - Porto Paglietto, LC - La Caletta, PV - Portovesme, PA - Punta S'Aliga, Fig. 1) were sampled in summer. Sampled sediments came from the upper $1-2 \mathrm{~cm}$ below the water column. The water temperature ranged between $27.7^{\circ} \mathrm{C}$ and $30.6^{\circ} \mathrm{C}$. Temperature, $\mathrm{pH}$, and Eh were measured for both the seawater and pore water of the sediments in every sampling station. Blank samples were also collected for comparison purposes at the same bathymetry and temperature from an unpolluted coastal area (NP - Portopauleddu, Fig. 1). Benthic foraminifera assemblages and their biodiversity indices, as well the geochemical characterisation of the investigated area, was the aim of our

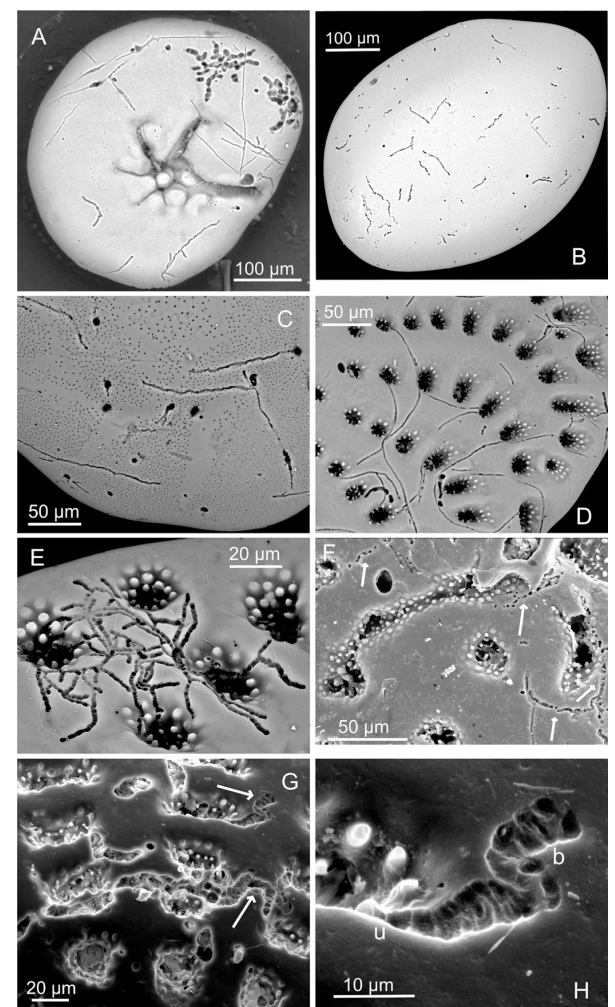

Fig. 3. SEM images of surface bioerosion of hyaline perforate foraminifera. (A) Rosalina bradyi Cushman (umbilical side) exhibiting indeterminable filaments and, at right, two bunches of radiating tunnels (cf. Fascichnus ). (B) Polymorphina sp. (oblique side view) showing filaments of indeterminable borings in the whole test. (C) Detail of Ammonia tepida (Cushman) spiral side intensively bored by long filaments of fungal hyphae with reproductive organs (cf. Saccomorpha clava). (D) Elphidium crispum (Linnaeus) showing in dorsal view a boring pattern of curved thin tunnels (1$2 \mu \mathrm{m}$ in diameter) belonging to cf. Scolecia filosa, goings towards the primary pores of the foraminifer. (E) Densely ramified boring pattern of Ichnoreticulina elegans, characterised by dichotomous branching goings into the primary pores of E. crispum. (F) Invasive colonies of indeterminable microborings (most likely bacteria, possibly cyanobacteria) around and into primary pores of E. crispum (arrows) producing a lateral enlargement of these until two-three contiguous pores join (cf. Freiwald, 1995; Fig. 4). (G) Boring system developed among contiguous pores of E. crispum, characterised by large tunnels (arrows). (H) Enlargement of (G) showing large microbial overprint going into the pore and its transition from uniseriate (u) to biseriate (b) cell arrangements, belonging to Fascichnus.

earlier paper, in order to assess the foraminiferal response to heavy metal pollution (Cherchi et al., 2009).

A cluster of four subsamples of constant volume $\left(50 \mathrm{~cm}^{3}\right)$ from every station (PP, LC, PV, PA) was collected to study foraminifera assemblages used as environmental bioindicators. In laboratory, 16 subsamples were stained with Rose Bengal (Walton, 1952) to differentiate living from dead specimens. Samples were then washed through a set of nested 
sieves $(63,125,180,250 \mu \mathrm{m})$. Foraminifera from $5 \mathrm{cc}$ of the $>125 \mu \mathrm{m}$ size fraction (a - medium grained) and $5 \mathrm{cc}$ of the $<125 \mu \mathrm{m}$ size fraction ( $\mathrm{b}$ - fine-grained) were picked, counted and classified.

Considering the very low number (1-4\%) of living individuals in the polluted environments (mainly at the PV and PA stations), total benthic foraminifera assemblages (dead and living) were used for statistical purposes, providing a larger database (Scott and Medioli, 1980; Samir and ElDin, 2001; Fatela and Taborda, 2002; Armynot du Châtelet et al., 2004; Debenay and Guiral, 2006; Frezza and Carboni, 2009). Total assemblages are almost identical statistically and only diverge when the living/total becomes large (Murray, 1976, 1991) and biotic indices do not show significant differences between living and dead populations (Yanko et al., 1994). Occurrence of iron-oxy-hydroxides in bottom sediments, pyritized infaunal benthic foraminfera and framboidal pyrite in the tests from the polluted sampling stations were occasionally found indicating reducing conditions.

Environmental scanning electron microscopy (ESEM) images allow recognition of an extensive infestation by microbial communities in the calcareous foraminiferal tests. The bioerosional process on foraminiferal tests was analysed via ESEM (QUANTA 200, FEI, Hillsboro, Oregon, and partly with EVOLS15, ZEISS). The epoxy resin casts of foraminifera were made at Erlangen University (Germany). Samples were gold coated before imaging, for analysis of both external surface and on epoxy-resin cast (Golubic et al., 1970, 1983; Wisshak et al., 2008). From ESEM images, microbial filaments and boreholes on the external surfaces have been compared with positive epoxy resin casts, and measured. To estimate quantitatively the impact of the microbial borings on the foraminifera and the selective bioerosion on high-Mg and low-Mg foraminiferal tests, 300 individuals were picked randomly from the fraction $>63 \mu \mathrm{m}$ of each sample and were observed with a scanning electron microscope. A total of 1200 foraminifera was examined. The bioerosional features on several morpho-structural taxa have been quantitatively calculated. The percentage of calcareous dissolution in foraminifera, distinguishing between high- $\mathrm{Mg}$ and low-Mg tests, has been compared with heavy metal values both in foraminiferal tests and the sediments, the $\mathrm{pH}$ of pore waters and richness of specimens.

Seawater was collected at the water-sediment interface of the 4 polluted stations and at the reference pollution-free station. After sampling seawater was rapidly filtered in situ through a $0.4 \mu \mathrm{m}$ pore-size polycarbonate filter with an allplastic filtration assembly. Samples for cation analysis were acidified with $\mathrm{HNO}_{3}$ suprapure acid to $\mathrm{pH}$ around 3. At each sampling site, temperature, $\mathrm{pH}$, and Eh were measured for both seawater and sediment porewater. The Eh was measured by platinum electrode and the value was corrected against Zobell's solution (Nordstrom, 1977). The electrode used for $\mathrm{pH}$ potentiometric determination was calibrated against three NIST-traceable buffer solutions $(\mathrm{pH}=4.01,7.00,9.00$ at
298 K). Reproducibility of $\mathrm{pH}$ calibrations, carried out before and after measurements of a single solution, was better than $0.005 \mathrm{pH}$ unit. However because of problems inherent to the use of glass electrodes calibrated using NIST buffers in strong electrolyte solutions (see Dickson and Goyet, 1994), this measurement was only used to verify the solution electrochemical difference between the different sampled stations.

Anions were determined by ion chromatography (IC Dionex DX-120) and cations by ICP-AES (ARL-3520B) or ICP-MS (Perkin Elmer DRC-e). Because of the complex seawater matrix, the standard addition method, was employed for the trace element determination $(\mathrm{Cd}, \mathrm{Pb}$ and $\mathrm{Zn}$ ) (Danzer and Currie, 1998; Cidu, 1999). The method validation was verified by applying the same conditions to the CASS-3 coastal seawater reference material. Samples and CASS-3 were diluted five times with a $1 \%$ ultrapure $\mathrm{HNO}_{3}$ solution before sample spiking. Accuracy and precision were estimated at $10 \%$ or better using the standard reference solution and random duplicate samples. The limit of quantification ( $10 \sigma$ value of blank solution response over time) was, respectively $0.01 \mu \mathrm{g}{ }^{-1}$ for $\mathrm{Cd}, 0.6 \mu \mathrm{g}{ }^{-1}$ for $\mathrm{Pb}$ and 0.1 for $\mathrm{Zn}$. The ionic balance was always in the order of $\pm 8 \%$.

For digestion of samples with porcelanaceous foraminiferal tests, two portions of each sample were washed with ultrapure water $\left(\mathrm{MilliQ}^{\circledR}\right)$ by mechanical agitation in order to remove detrital grains. The samples were dried, accurately weighed and digested by slow heating in a temperature bath at $30^{\circ} \mathrm{C}$ in a Teflon beaker with $3 \mathrm{ml}$ of ultrapure $\mathrm{HNO}_{3}(67 \%)$. Solutions were diluted to $10 \mathrm{ml}$ with ultrapure water in volumetric flasks, and transferred to new HD-polyethylene bottles for storage (Jarvis, 1992). Metals were determined by ICP-AES and ICP-MS.

Field Emission Gun SEM (FEG-SEM) is a scanning electron microscope with a high-energy beam of electrons in a raster scan pattern producing information about surface topography and composition. The Quanta 200 FEG Environmental Scanning Electron Microscope (ESEM) uses a fieldemission gun (FEG) electron source in an exceptionally high chamber pressure environment. It combines the advantages of nanometer resolution to high signal to noise ratio in both regular high vacuum and environmental (wet) modes. EDX Analysis stands for energy-dispersive X-ray analysis; it is sometimes referred to as EDS or EDAX. EDX analysis allows identification of the elemental composition of the specimen, or an area of interest thereof. The EDX analysis system works as an integrated feature of a scanning electron microscope (SEM), and can not operate on its own without the latter. 
Table 1. Distribution on microborings at different sampling stations (PP, LC, PV and PA, see Fig. 1), taken from porcelanaceous (Po) and hyaline $(\mathrm{Hy})$ foraminiferal substrates and their relative abundance $(++$ very common, + common, $=$ rare $)$.

\begin{tabular}{|c|c|c|c|c|c|c|c|c|c|}
\hline \multirow[b]{2}{*}{ Foraminifera substrata } & & \multicolumn{2}{|c|}{ PP } & \multicolumn{2}{|c|}{ LC } & \multicolumn{2}{|c|}{ PV } & \multicolumn{2}{|c|}{ PA } \\
\hline & & Po & Hy & Po & Hy & Po & Hy & Po & Hy \\
\hline Borings & Trace-makers & & & & & & & & \\
\hline Eurigonum nodosum & Mastigocoleus testarum & $X$ & & $\mathrm{X}$ & & $\mathrm{X}$ & $\mathrm{X}$ & XX & $X$ \\
\hline Schmidt & Lagerhein (cyanophyte) & & & & & & & & \\
\hline $\begin{array}{l}\text { Fascichnus cf dactylus } \\
\text { (Radtke) }\end{array}$ & $\begin{array}{l}\text { Hyella caespitosa Bornet } \\
\text { and Flahault (cyanophyte) }\end{array}$ & & & $\mathrm{X}$ & & $\mathrm{XX}$ & $\mathrm{X}$ & $\mathrm{XX}$ & $\mathrm{X}$ \\
\hline Scolecia filosa & Plectonema terebrans & $\mathrm{X}$ & $\mathrm{X}$ & & $\mathrm{X}$ & $\mathrm{XX}$ & $\mathrm{X}$ & $X$ & $X$ \\
\hline Radtke & Bornet and Flahault (cyanophyte) & & & & & & & & \\
\hline Scolecia meandria & "vermicular borings" & & & & & & & $\mathrm{X}$ & \\
\hline Radtke & (Zeff and Perkins, 1979) (cyanophyte) & & & & & & & & \\
\hline $\begin{array}{l}\text { cf. Planobola macrogota } \\
\text { Schmidt }\end{array}$ & $\begin{array}{l}\text { cyanobacterium cf. } \\
\text { alga } \mathrm{cf} .\end{array}$ & & & & & $\mathrm{X}$ & $\mathrm{X}$ & $\mathrm{X}$ & \\
\hline $\begin{array}{l}\text { cf. Cavernula pediculata } \\
\text { Radtke }\end{array}$ & $\begin{array}{l}\text { Gomontia polyrhiza } \\
\text { (Lagerhein) Bornet and } \\
\text { Flahault (chlorophyte) }\end{array}$ & & & & $\mathrm{X}$ & $\mathrm{X}$ & & & $\mathrm{X}$ \\
\hline $\begin{array}{l}\text { Ichnoreticulina elegans } \\
\text { (Radtke) }\end{array}$ & $\begin{array}{l}\text { Ostreobium quekettii } \\
\text { Bornet and } \\
\text { Flahault (chlorophyte) }\end{array}$ & & $\mathrm{XX}$ & & $\mathrm{XX}$ & $\mathrm{X}$ & $\mathrm{X}$ & & $\mathrm{X}$ \\
\hline Rhopalia catenata & Phaeophila dendroides & & $=$ & & $\mathrm{X}$ & & $\mathrm{X}$ & & \\
\hline Radtke & Cronan (chlorophyte) & & & & & & & & \\
\hline Orthogonum fusiferum & Ostracoblabe implexa & & & $X$ & & $\mathrm{X}$ & & $\mathrm{X}$ & \\
\hline Radtke & Bornet and Flahault (fungus) & & & & & & & & \\
\hline Orthogonum lineare Glaub & cf. fungus & & & $=$ & & XX & $X$ & $X$ & $\mathrm{X}$ \\
\hline $\begin{array}{l}\text { Orthogonum isp. (Form } 1 \\
\text { in Wisshak et al., 2005) }\end{array}$ & & & & & & $\mathrm{X}$ & & & \\
\hline Saccomorpha clava & Dodgella priscus & $=$ & & $X$ & $=$ & $\mathrm{XX}$ & $\mathrm{X}$ & XX & $\mathrm{X}$ \\
\hline Radtke & Zebrowski (fungus) & & & & & & & & \\
\hline & Coccoid bacteria & & & & & $\mathrm{XX}$ & $X$ & $\mathrm{X}$ & \\
\hline
\end{tabular}

\section{Results and discussion}

\subsection{Bioerosion features}

The presence of microboring traces and cavities on sampled benthic foraminifera has been recognised using ESEM images of both surface tests and epoxy resin casts. Identified taxa, reported in Table 1, provide evidence of traces and cavities produced by phototrophic (cyanobacteria, chlorophyta) and heterotrophic (fungi) organisms. In Figs. 2 to 6, we illustrate evidence of several endolithic traces of microbial borings with morphological differences. Details of borings will be described according to the different observational techniques: wall surfaces and epoxy resin casts.

Test surfaces of the porcelanaceous miliolids present the heaviest bioerosion features under the form of microbial clusters. Endolithic traces have morphological differences related to biodiversity and to mode of life of the boring microbial organisms. Infestation is characterised by thin individual tunnels, occasionally bifurcated, bag-shaped cavities and branching patterns composed by rhizoidal and short galleries radiating laterally from the central area. This branch- ing pattern shows similarities with Fascichnus isp. (Fig. 7a, b). From ESEM images of the traces on external surfaces of foraminiferal tests, our observations show that the taxa affected by higher bioerosion belong to the high-Mg porcelanaceous group (Suborder Miliolina) and, among these, to the genus Quinqueloculina which exhibits heavy microbial bioerosion. Figure 8 shows that in Quinqueloculina sp. the $\mathrm{Mg}$ content at the bottom of a boring is one order of magnitude lower compared to the unaltered shell surface, suggesting chemical reorganisation of the carbonate mineral composition through a dissolution-precipitation process.

In several specimens the infestation is concentrated along the sutures of the chamber walls providing more easily a nutrient source (Fig. 2b). A heavy infestation by diversified microborings in the test of Triloculina has been recorded (Fig. 2c). Radiating traces are developed parallel to the whole surface of foraminifers, in both porcelanaceous and hyaline types (Fig. 3 a,g,h and Fig. 7b), as previously observed by Glaub (2004) for "Fasciculus isp. 2". Lined rodshaped bacteria are sometimes visible on the later chambers of Adelosina among their weakly developed striae. These 


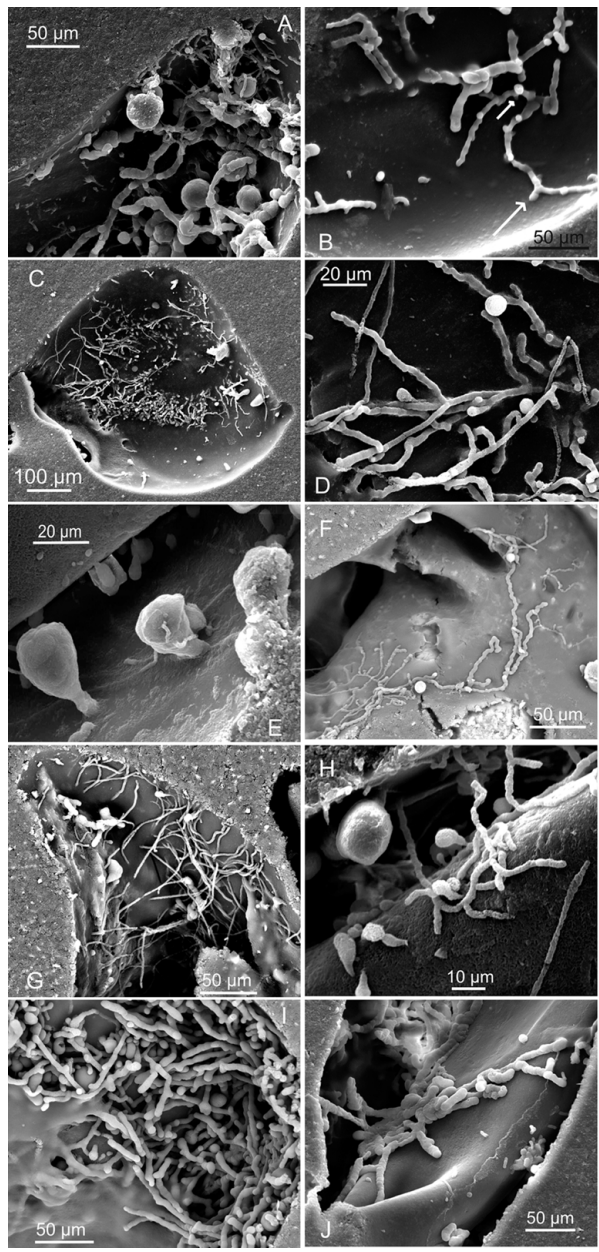

Fig. 4. SEM images of porcelanaceous foraminifera resin casts. (A) Chamber-wall of miliolid densely bored by Eurigonum nodosum and globular Saccomorpha clava. (B) E. nodosum with diagnostic lateral heterocysts (arrows) inside the thick chamber wall of miliolid. (C) Dense assemblage of euendolithic borings in miliolid test. (D) Enlargement of (C) showing E. nodosum with diagnostic heterocysts. (E) Pavement of Saccomorpha clava into miliolid chamber wall. (F) Colony of Scolecia meandria in miliolid chamber wall. (G) Microbial pavement in miliolid chamber wall exhibiting Scolecia filosa, E. nodosum and fungal sack-shaped cavities. (H) Diversified ichnotraces belonging to S. clava, cf. Planobola macrogota and Ichnoreticulina elegans in miliolid test. (I) Dense colonies of E. nodosum in miliolid test. (J) Colonies of E. nodosum inside the thick chamber wall of miliolid.

cryptoendoliths bacteria (sensu Golubic et al., 1981) can go into pre-existing holes, characterised by a larger diameter, clearly bored previously by another larger boring organism (Fig. 2d). Hyaline perforated tests (e.g. Elphidium crispum) frequently exhibit well-organised systems of microborings belonging to Ichnoreticulina elegans surrounding and directed to pores (Fig. 3e). Bacteria infestation can produce teratological modifications as observed in E. crispum (Fig. 3f) where bacteria colonies induce lateral enlargement of pri-
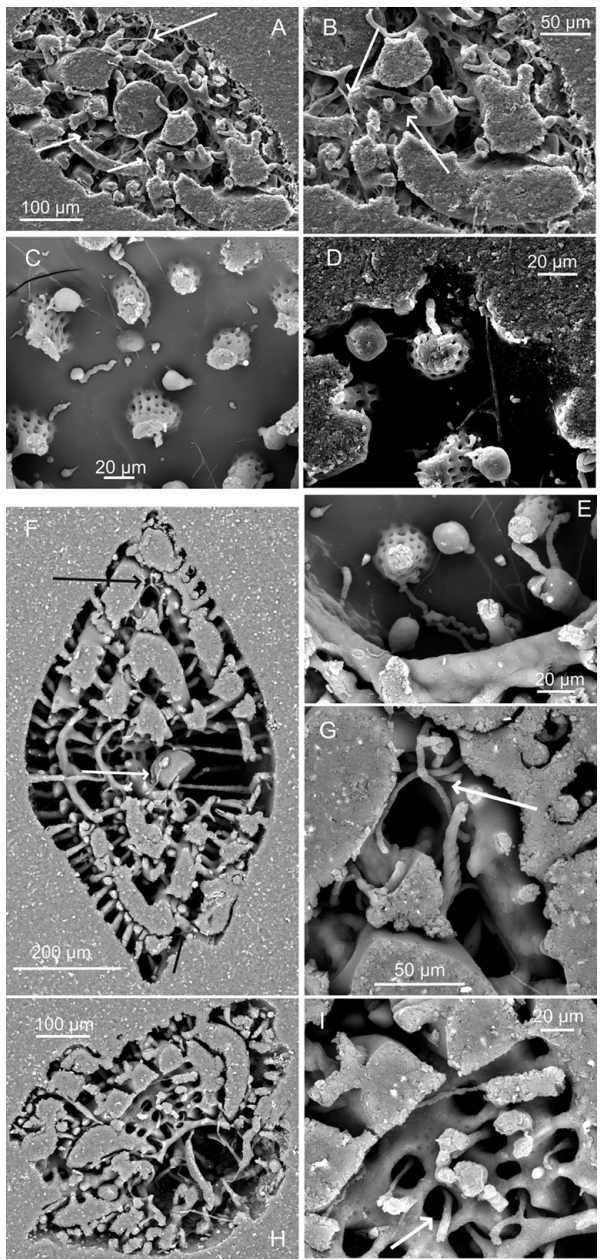

Fig. 5. SEM images of hyaline foraminifera resin casts. (A) Euendoliths (arrows) inside the skeletal structure of Elphidium crispum (Linnaeus). (B) Enlargement of (A) showing indeterminable filaments. (C) and (D) Saccomorpha clava and indeterminable cyanobacteria boring skeletal structure of E. crispum. (E) Enlargement of (D) showing spherical cavities of cf. Planobola macrogota and sack-shaped cavity of cf. Cavernula. (F) E. crispum (vertical section) showing indeterminable filamentous (arrows) in the complex skeletal pattern. (G) Enlargement of (F) showing filaments inside the skeletal of the foraminifera. (H) E. crispum (oblique section). (I) Enlargement of (H) showing tunnels (arrows) of borings in skeletal structures.

mary pores with enlargement of contiguous pores (cf. Freiwald, 1995, in Cibicides lobatulus). Superficial traces made by endolithic boring communities can completely cover the walls (Fig. 3a-c).

Several specimens of E. crispum show a boring pattern made of curved tunnels of $1-2 \mu \mathrm{m}$ in diameter. Tunnels, after long runs, go towards the primary pores showing a comparable behaviour to I. elegans and they are tentatively attributed to Scolecia filosa. Infestation producing the primary pore connection may be related to possible $\mathrm{CO}_{2}$ bioavailability 


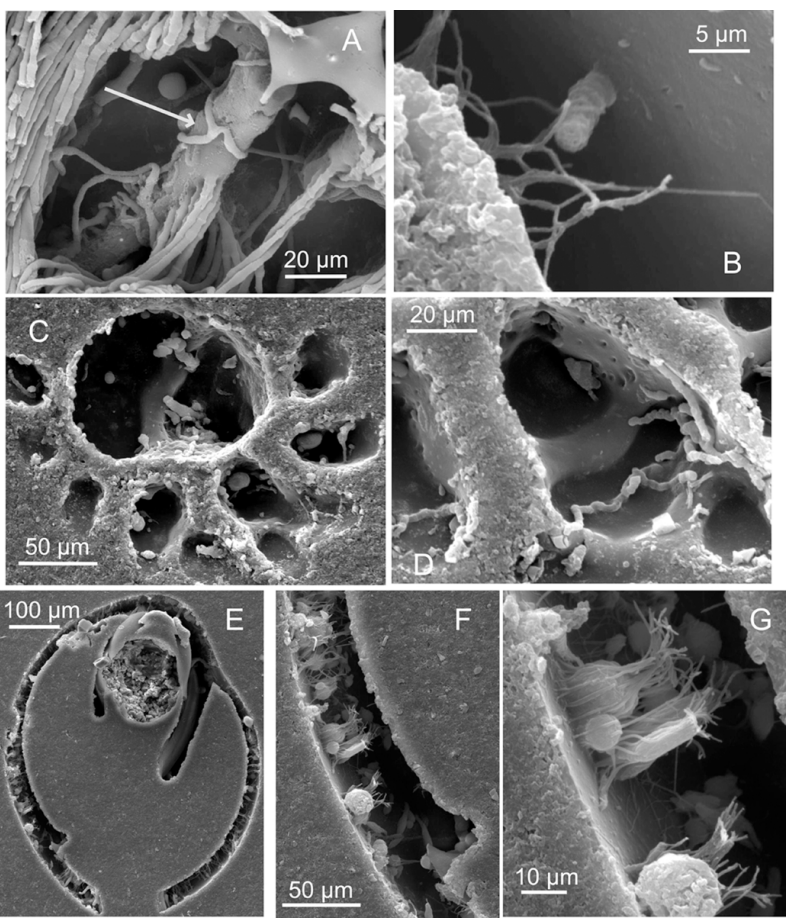

Fig. 6. SEM images of hyaline foraminifera resin casts. (A) Tripartite gallery of underteminable boring (cf. Orthogonum sp.) and globular-shape cavities in skeletal structure of Ammonia beccarii (Linnaeus). (B) Ichnoreticulina elegans in Ammonia sp. (C) Euendoliths inside the peripherical wall chambers of Ammonia tepida (Cushman). (D) Colony of Eurigonum nodosum in Ammonia sp. (E) Pavement of spherical cavities in the finely perforate test of Polymorphina sp. (F) and (G) Enlargement of (D) showing spherical cavities of cf. Planobola macrogota and sack-shaped cavities of cf. Cavernula surrounded by foraminiferal tubules.

for phototrophic organisms from the respiratory activity of the heterotrophic host.

Epoxy resin casts reveal rich microbial communities, fairly diversified, both in porcelanaceous and hyaline tests (Table 1). Analysis of resin casts reveals euendoliths belonging to phototrophic (chlorophyta, cyanobacteria) and heterotrophic (fungi) organisms boring both porcelanaceous and hyaline foraminifera. The wider and thicker walls of miliolids provide a protected niche for the growth of euendoliths, as shown in Fig. 4. In porcelanaceous tests, dense pavements of well-developed colonies of cyanobacteria and fungal sporangial cavities are very common. The presence of organic films inside the skeleton structure of these foraminifera provides a source of food.

The ichnological interpretation of the euendoliths inside the imperforate porcelanaceous tests is easier than for those inside the perforate hyaline hosts. The very complex internal architecture of the taxa belonging to the families Elphidiidae and Rotaliidae sometimes makes it difficult to distinguish euendoliths from foraminifera ultrastructures (Figs. 5 and 6). Even if the ichnological attribution of the euendoliths
Table 2. Seawater composition at the four sampling stations.

\begin{tabular}{llrrrr}
\hline & & PP & LC & PV & PA \\
\hline $\mathrm{pH}$ & & 8.23 & 8.21 & 8.13 & 7.91 \\
$\mathrm{Eh}$ & $\mathrm{V}$ & 0.35 & 0.36 & 0.34 & 0.37 \\
$T$ & ${ }^{\circ} \mathrm{C}$ & 27.7 & 27.9 & 29.6 & 30.6 \\
$\mathrm{Ca}$ & $\mathrm{moll}^{-1}$ & 0.011 & 0.012 & 0.011 & 0.011 \\
$\mathrm{Mg}$ & $\mathrm{moll}^{-1}$ & 0.058 & 0.059 & 0.057 & 0.058 \\
$\mathrm{~K}$ & $\mathrm{moll}^{-1}$ & 0.012 & 0.012 & 0.012 & 0.012 \\
$\mathrm{Na}$ & $\mathrm{moll}^{-1}$ & 0.480 & 0.482 & 0.472 & 0.483 \\
$\mathrm{SO}_{4}$ & $\mathrm{moll}^{-1}$ & 0.037 & 0.040 & 0.043 & 0.037 \\
$\mathrm{CI}$ & $\mathrm{moll}^{-1}$ & 0.604 & 0.592 & 0.564 & 0.564 \\
$\mathrm{HCO}$ & $\mathrm{moll}^{-1}$ & 0.002 & 0.002 & 0.002 & 0.002 \\
$\mathrm{Br}$ & $\mathrm{moll}^{-1}$ & 0.001 & 0.001 & 0.001 & 0.001 \\
$\mathrm{Ba}$ & $\mathrm{moll}^{-1}$ & 0.053 & 0.052 & 0.058 & 0.076 \\
$\mathrm{Cd}$ & $\mathrm{moll}^{-1}$ & 0.002 & 0.002 & 0.002 & 0.004 \\
$\mathrm{Li}$ & $\mathrm{moll}^{-1}$ & 19.882 & 20.602 & 19.882 & 20.314 \\
$\mathrm{Mo}$ & $\mathrm{moll}^{-1}$ & 0.125 & 0.136 & 0.125 & 0.125 \\
$\mathrm{~Pb}$ & $\mathrm{moll}^{-1}$ & 0.010 & 0.014 & 0.016 & 0.016 \\
$\mathrm{Sr}$ & $\mathrm{moll}^{-1}$ & 91.589 & 93.460 & 93.232 & 94.122 \\
$\mathrm{Zn}$ & $\mathrm{moll}^{-1}$ & 0.061 & 0.076 & 0.061 & 0.076 \\
\hline
\end{tabular}

in the hyaline perforate taxa is generally uncertain, their presence in the fine skeletal structure indicates that microbial colonies can use foraminiferal canal-systems to penetrate inside the test, and subsequently to develop boring activity in the foraminiferal skeleton.

Our study shows that microbioerosion affects porcelanaceous (high-Mg) imperforate miliolids (Adelosina, Pseudotriloculina, Quinqueloculina and Triloculina) and peneroplids as well as hyaline (low-Mg) perforate foraminifera (Ammonia, Elphidium, Lobatula, Rosalina) (Fig. 9). Porcelanaceous miliolids (Quinqueloculina and Triloculina spp.) exhibit higher percentages of bioerosional features in PA station $(28.72 \%)$ and in PV station $(21.75 \%)$ while hyaline $L o$ batula lobatula and Elphidium crispum reveal higher values of microbial infestation in PA $(16.89 \%)$ and LC stations $(15.02 \%)$, respectively. In particular, Elphidium tests show well-developed colonies of Ichnoreticulina elegans surrounding and directed to primary pores. The clorophyceans in our samples seem to be more frequent in less polluted sediments (LC). Figure 10a and $\mathrm{b}$ show that the number of infested tests is 2 times higher in porcelanaceous compared to hyalines foraminifera and that the proportion of infested tests is 2-3 times higher in the lowest $\mathrm{pH}$ conditions. Bioerosion in hyaline specimens increases from $19.9 \%$ (PP) to $59.7 \%(\mathrm{PA})$, whereas in a porcelanaceous forms it increases from $35.1 \%$ (PP) to $80.3 \%$ (PA). Our observations demonstrate that taxa affected by higher bioerosion belong to the high-Mg porcelanaceous group (Suborder Miliolina), especially Quinqueloculina. Infestation is often concentrated along the chamber wall sutures where nutrient material is high (Fig. 2b). Diversified microborings on an infested test of Triloculina are illustrated in Fig. 2c. 


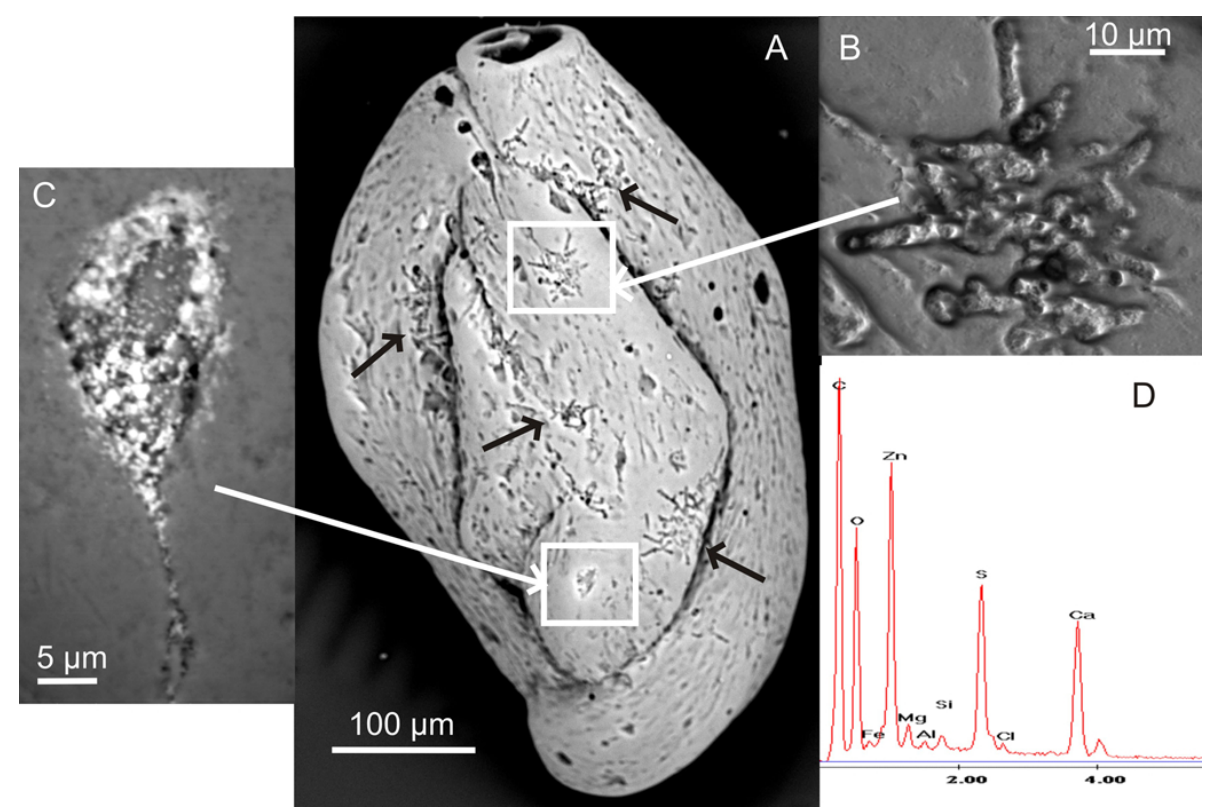

Fig. 7. SEM images of porcelanaceous foraminifera. (A) Quinqueloculina cf. berthelotiana d'Orbigny intensively bored by euendoliths (black arrows) among which are colonies of Fascichnus cf. dactylus. (B) Enlargement of (A) exhibiting a well-developed colony of $F$. cf. dactylus characterised by tunnels radiating from a central area. (C) Enlargement of (A) showing dome-shaped cavity of cf. Cavernula pediculata with rhizoidal appendages, Zn biomineralised. (D) EDX analysis of dome-shaped cavity of cf. Cavernula pediculata.

\subsection{Environmental conditions and bioerosion}

Seawater composition from four sampled stations is given in Table 2. As previously reported porcelanaceous foraminiferal tests, known to be high-Mg foraminifera, are more infested by bioerosion than hyaline forms. We found that $\mathrm{Mg} / \mathrm{Ca}$ molar ratio of porcelanaceous infested tests is between 0.09 and 0.13 , while in foraminiferal tests collected from an unpolluted site (NP) without an apparent sign of bioerosion have a $\mathrm{Mg} / \mathrm{Ca}$ value of 0.01 (Fig. 10c). Since $\mathrm{Mg} / \mathrm{Ca}$ molar ratio of benthic foraminifera is normally assumed to be between 0.0005 and $0.01 \mathrm{~mol} \mathrm{~mol}^{-1}$ (Lea, 1999; Toler et al., 2001; Toyofuku and Kitazato, 2005), we propose that conditions of environmental stress may influence the amount of $\mathrm{Mg}$ incorporated during the foraminifera's growth. Our results are in agreement with the experimental investigation on $\mathrm{Mg}$ intrashell reactions of Bentov and Erez (2005) and which are attributed to a kinetic mechanism played by the carbonate ions in the calcite growth by Lopez et al. (2009). Porcelanaceous foraminiferal tests from the anthropogenically polluted lagoon of Santa Gilla (Frontalini et al., 2009) have a similar $\mathrm{Mg} / \mathrm{Ca}$ ratio $\left(0.11 \mathrm{~mol} \mathrm{~mol}^{-1}\right)$ which is greater than that collected at station NP, confirming the influence of the stressed environment on the $\mathrm{Mg} / \mathrm{Ca}$ ratio of these biominerals.
Figure 10d shows that the amount of $\mathrm{Cd}, \mathrm{Zn}$ and $\mathrm{Pb}$ incorporated in the bioinfested shells in PP, LC, PV and PA is higher compared to the pollution-free NP station. We found that the amount of heavy metals incorporated in the infested tests is higher when the proportion of infested tests is higher.

The process of bioerosion in calcareous skeletal structures can be regarded differently in high-Mg porcelanaceous imperforate tests and low-Mg bilamellar hyaline perforate tests and can also be related to the decrease of seawater $\mathrm{pH}$ (Fig. 10b). The porcelanaceous wall consists of a thick layer of high-Mg calcite needles with relatively large interstices filled with organic matter. Needles are randomly arranged and coated inside by an inner organic lining and outside by the outer organic layer (Towe and Cifelli, 1967; Hemleben et al., 1986; Debenay et al., 2000a). The common infestation of euendoliths in porcelanaceous tests rather than in hyaline tests can also be related to the thick calcite layer of the porcelanaceous wall, allowing an adequate erosional space for their growth. The perforate foraminifera are characterised by structures of greater complexity (chamber-partitions, shell cavities, canal systems) compared with those of the porcelanaceous group. In the bilamellar hyaline perforate group, the wall comprises carbonate layers separated by an organic median layer (Towe and Cifelli, 1967; Hansen and Reiss, 1971; Hottinger, 1978, 2000; Hansen, 1999; Debenay et al., 2000b). Our data show that increasing heavy metal concentrations in the sediments corresponds to an increase of microbial infestation, reaching a peak at the more polluted sites (PV and PA; Fig. 10e). 


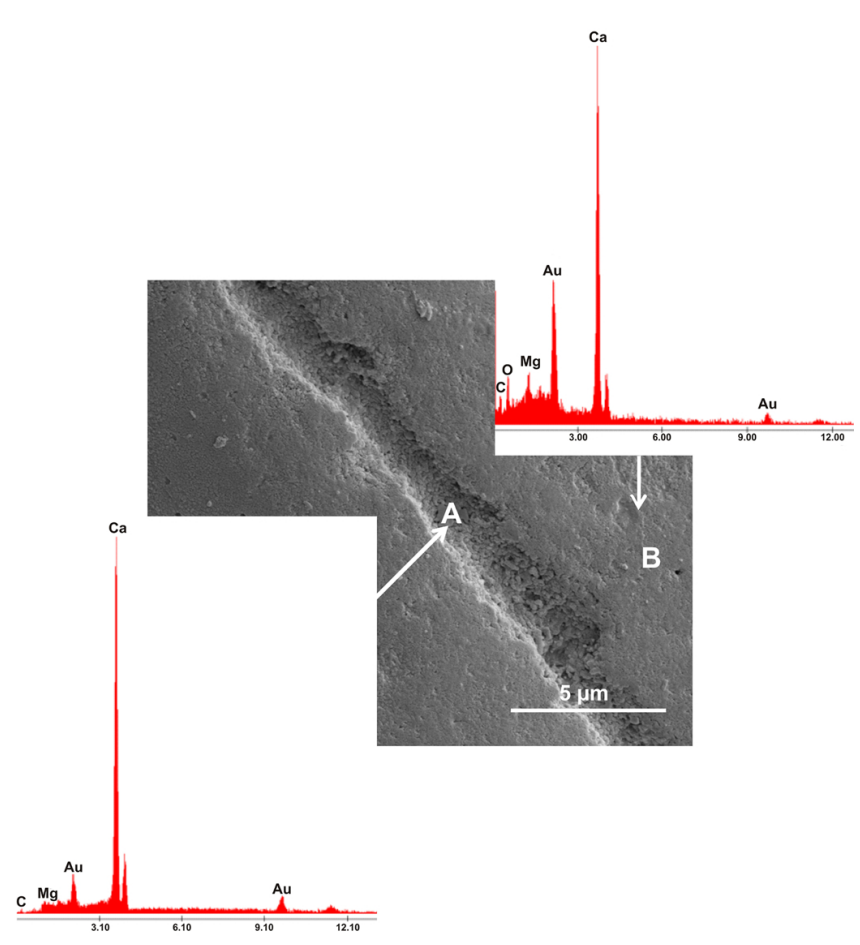

Fig. 8. SEM FEG images of porcelanaceous foraminifera (Quinqueloculina sp.). EDX analysis shows that $\mathrm{Mg}$ content at the bottom of boring (A) is significantly lower than on unaltered shell surface (B).

The observed high level of microboring infestation is related to the anomalous mechanism of bio-mineral construction in the presence of a high level of heavy metals. In these heavily polluted environments, euendolithic bioerosion develops in small shells of the biocarbonate substrates such as calcareous foraminifera. Microbial organisms need the development of a trophic strategy related to the decrease of micrograzers (mainly benthic foraminifera). According to Mojtahid et al. (2011) some foraminifera species, such as Haynesina germanica, Ammonia beccarii and the singlechambered species Psammophaga sp., consume and digest large quantities of bacteria. The estimated grazing rates of these three intertidal species were comparable: $\sim 3.2 \mathrm{ng}$ Cind $^{-1} \mathrm{~h}^{-1}\left(\sim 16000\right.$ bacterial cells ind $\left.^{-1} \mathrm{~h}^{-1}\right)$ for low bacterial concentration $\left(\sim 43 \times 10^{6}\right.$ cells $)$ and $\sim 5.7 \mathrm{ng} \mathrm{C}$ ind $^{-1} \mathrm{~h}^{-1}\left(\sim 28000\right.$ bacterial cells ind $\left.{ }^{-1} \mathrm{~h}^{-1}\right)$ for higher bacterial concentration $\left(\sim 86 \times 10^{6}\right.$ cells $)$. Biotic indices (Faunal Density, Species Richness, Dominance, ShannonWeaver, Simpson, Evenness, Menhinick, Margalef, Equitability, Fisher- $\alpha$, Berger-Parker; Cherchi et al., 2009) performed on foraminiferal assemblages show an abrupt decrease with increasing heavy metal fluxes (Fig. 10a, d). Optical observations reveal an high number of abnormal and small specimens in accordance with an increase of industrial pollution. Morphological abnormalities, which are commonly found in tests from pollution-stressed benthic foraminiferal populations, may be related to incorporation of

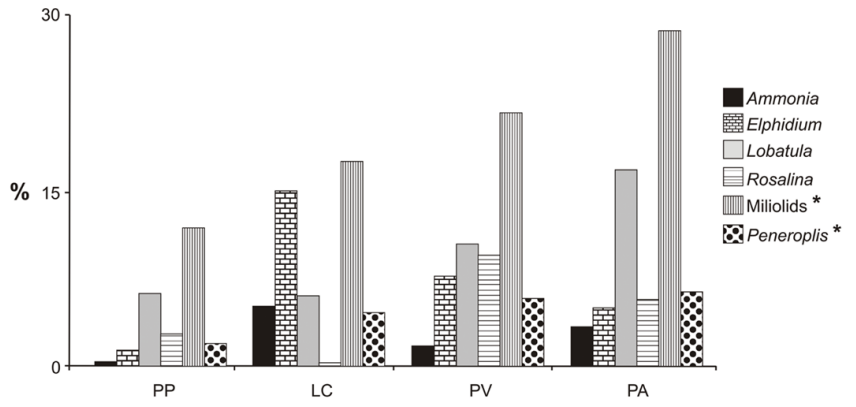

Fig. 9. Occurrence of bioerosion given in percent in selected taxa belonging to porcelanaceous (high-Mg) imperforate miliolids and peneroplids (*) and hyaline (low-Mg) perforate foraminifera ( $\mathrm{Am}$ monia, Elphidium, Lobatula, Rosalina) from sampling stations (PP, LC, PV, PA).

higher concentrations of $\mathrm{Mg}$ and other elements from seawater into their tests (Yanko et al., 1994, 1998).

In the sandy beach part of the study area, limestone outcrops are lacking and bottom sediment is made of quartz grains. Anomalous concentrations of euendolithic communities in shallow polluted waters, question the capacity of intensive industrial activity to produce extreme environmental conditions in restricted local areas only. Mine waste containing toxic concentrations of heavy metals $(\mathrm{Fe}, \mathrm{Al}, \mathrm{Cu}, \mathrm{Zn}$, $\mathrm{Cd}, \mathrm{Pb}, \mathrm{Ni}, \mathrm{Co}$ and $\mathrm{Cr}$ ) discharged into aquatic systems may produce degradation of water quality and aquatic life (Nordstrom, 2011). Our study reveals that peculiar environments affected by heavy metal fluxes from industrial processing are not biologically dead as they are teeming with microbes, including bacteria, archaea, fungi and algae.

Global scale geochemical models that predict the carbonate saturation state of the surface waters in the twenty-first century suggest that calcareous organisms may have difficulty calcifying, leading to production of weaker skeletons and greater vulnerability to erosion. We estimated the $p \mathrm{CO}_{2}$ partial pressure at equilibrium with the sampled seawater (by $\mathrm{pH}$ and alkalinity) using the Millero and Scheiber (1982) ion pairing model to estimate activity coefficients and found values between 3-5 times higher than the average for the open sea nearby. This study of biomineralisation confirms that, at least in shallow waters, high-Mg carbonates are altered faster compared to low-Mg carbonates (Fig. 10b), confirming that organisms using the more soluble forms of $\mathrm{CaCO}_{3}$ (aragonite and high-Mg calcite) are more adversely affected by higher $p \mathrm{CO}_{2}$. Our results are in agreement with earlier laboratory experiments (Morse, 1983; Morse et al., 2007) where it was predicted that dissolution of various benthic marine organisms may increase under natural higher $p \mathrm{CO}_{2}$ partial pressure (Ries et al., 2009). 

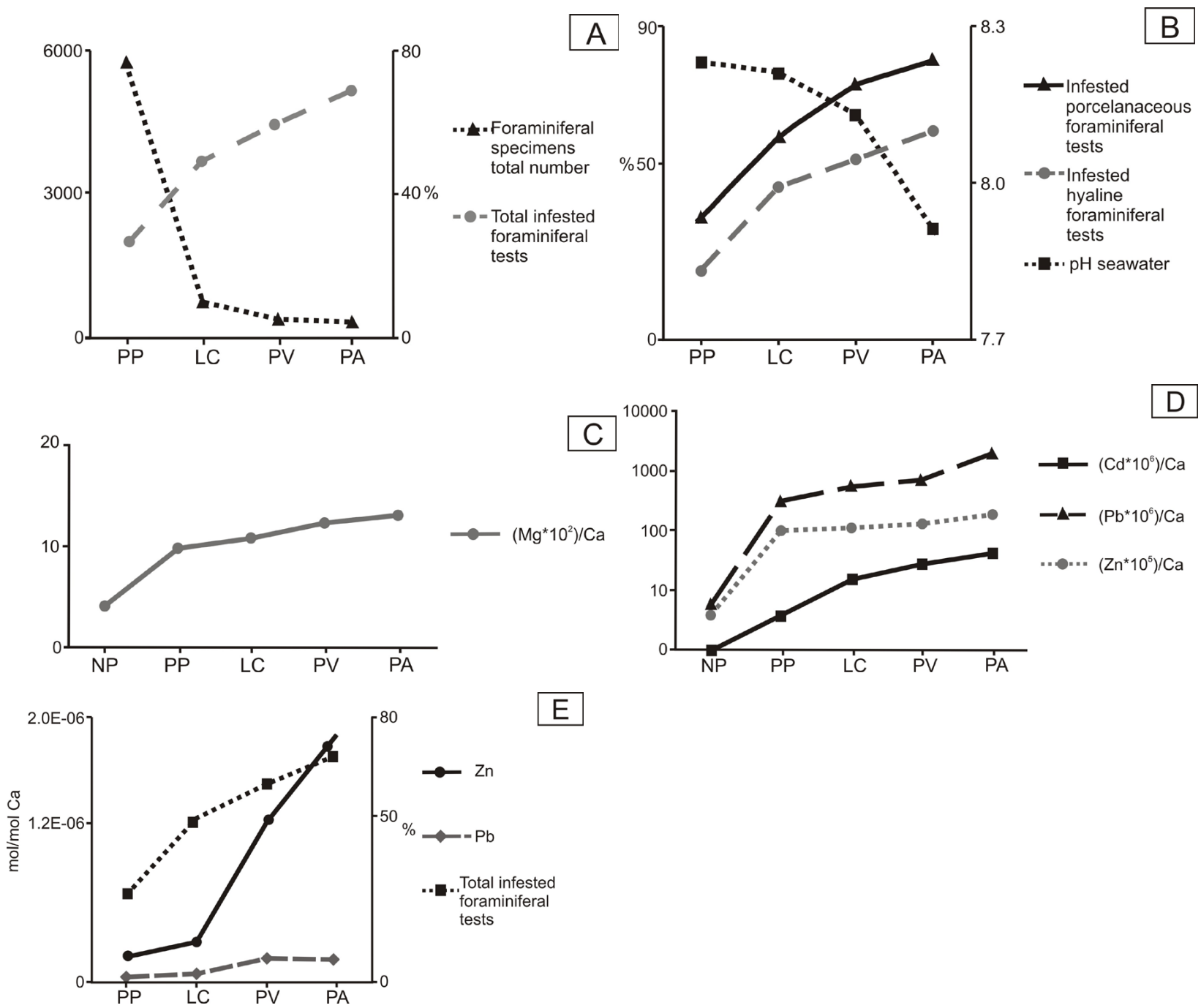

Fig. 10. Occurrence of bioerosion given in percent in microbially infested foraminiferal tests from Portoscuso coastal environments. (A) Correlation between infested foraminifera percentages and total number of foraminiferal tests. (B) Correlation between porcelanaceous high-Mg and hyaline low-Mg tests and sea water $\mathrm{pH}$. (C) $\mathrm{Mg} / \mathrm{Ca}$ ratio in foraminiferal tests increases in more highly polluted sites. (D) $\mathrm{Cd} / \mathrm{Ca}, \mathrm{Pb} / \mathrm{Ca}$ and $\mathrm{Zn} / \mathrm{Ca}$ ratio in foraminiferal tests increase in more highly polluted sites. (E) Increase of heavy metal values in sediments corresponds to increase in microbial infestation.

\section{Summary and conclusions}

In our study, samples were collected at the same depth (about $2 \mathrm{~m}$ ) from shallow sediments affected by serious industrial contamination in the coastal environments of PortoscusoPortovesme. In this area, foraminiferal shells have a high content of heavy metals and are actively infested by microborings. As far as we know, these infested foraminiferal communities provide a state-of-the-art dataset for the understanding of bioerosional processes in foraminiferal hosts in polluted environments.

The results show (i) microbioerosion is higher in high- $\mathrm{Mg}$ foraminiferal tests compared to the low-Mg tests, (ii) the role of foraminiferal skeletal architecture in the boring process, (iii) the abundance of euendoliths is favoured by the effect of greater concentrations of heavy metals, especially $\mathrm{Zn}$, as an inorganic nutrient.

We interpret that in the shallow water and low hydrodynamic conditions of the Portoscuso-Portovesme lagoon, the heavy metals leached from mine tailings and industrial discharge are not immediately dispersed in the sea water and, thus, foraminifera can concentrate heavy metals in their shells. This takes place in a complex biomineralisation process. In agreement with geochemical models and previous literature, we found that high-Mg carbonate shells dissolve faster and are deeply infested by microborings. While geochemical models already predict that $\mathrm{CO}_{2}$ increase is affecting biogenic carbonate reservoirs, this study demonstrates 
that the heavy metal dispersion process can contribute to global $\mathrm{CO}_{2}$ change via a complex ecological process.

Acknowledgements. The authors are very grateful to M. Wisshak (Senckenberg am Meer, Wilhelmshaven, Germany) for his help in the epoxy resin casts preparation, in the interpretation of the ichnotaxa inventory and for his useful suggestions which greatly improved the manuscript. We thank Rich B. Wanty (USGS, Denver) for his discussion and comments. We thank P. Meloni and G. Carcangiu (University of Cagliari, Italy) for their collaborative assistance during electronic microscopic analysis performed with EVOLS15, ZEISS microscope. We thank E. Musu for assistance with SEM-FEG imaging (DistrICT LAB, Sardegna Ricerche, Pula). This work was supported by the EU UMBRELLA Project (funding 226870). The authors express their sincere gratitude to Alan Lord (Forschungsinstitut Senckenberg, Frankfurt-am-Main) for the revision of the English text. The authors warmly thank Erika Kothe (Jena University), Elisabetta Erba (Milano University), anonymous reviewers and the editor for their useful comments and suggestions.

Edited by: H. Kitazato

\section{References}

Agenzia Regionale per la Protezione dell'ambiente della Sardegna (ARPAS): Determinazione dei valori di fondo nelle matrici ambientali dell'area di Portoscuso (CI), Progetto operativo, 29 pp., 2007.

Alexanderson, E. T.: Micritization of carbonate particles: Processes of precipitation and dissolution in modern shallow-marine sediments, Bulletin of the Geological Institutions of the University of Uppsala, N.S., 3, 201-236, 1972.

Al-Thukair, A. A.: Euendolithic micro-organisms found to bore the calcareous sediment of the Arabian Gulf, in: Proceedings of the Second International Conference on Engineering for Calcareous sediments, Bahrain, 21-24 February 1999, 291-299, 1999.

Al-Thukair, A. A.: Effect of oil pollution on euendolithic cyanobacteria of the Arabian Gulf, Environ. Microbiol., 4, 125-129, 2002.

Al-Thukair, A. A. and Golubic, S.: New endolithic cyanobacteria from the Arabian Gulf. I. Hyella immanis sp. nova, J. Phycol., 27, 766-780, 1991.

Al-Thukair, A. A., Abed, R. M. M., and Mohamed, L.: Microbial community of cyanobacteria mats in the intertidal zone of oilpolluted coast of Saudi Arabia, Mar. Pollut. Bull. 54, 173-179, 2007.

Alve, E.: Benthic foraminifera reflecting heavy metal pollution in Sørljord, Western Norway, J. Foraminifer. Res., 34, 1641-1652, 1991.

Alve, E.: Benthic foraminifera response to estuarine pollution, a review, J. Foraminifer. Res., 25, 190-203, 1995.

Armynot du Châtelet, E., Debenay, J. P., and Saulard, R.: Foraminiferal proxies for pollution monitoring in moderately polluted harbors, Environ. Pollut., 127, 27-40, 2004.

Bentov, S. and Erez, I.: Novel observations on biomineralisation processes in foraminifera and implications for $\mathrm{Mg} / \mathrm{Ca}$ ratio in the shells, Geology, 33, 841-844, 2005.
Bettini, V. and Zannin, D. (Eds.): Portoscuso, la gassificazione della V.I.A.-Il Gassificatore Ati-Sulcis, le problematiche ambientali connesse al progetto, CUEN, Napoli, Italy, 1-190, 2002.

Boyle, E. A.: Cadmium, zinc, copper, and barium in foraminifera tests, Earth Planet. Sc. Lett., 53, 11-35, 1981.

Budd, D. A. and Perkins, R. D.: Bathymetric zonation and paleoecological significance of (algal) microborings in Puerto Rican shelf and slope sediments, J. Sediment. Petrol., 50, 881-904, 1980.

Campbell, S. E.: Petrochemical pollution: endolith response, in: $\mathrm{VI}^{\mathrm{es}}$ jornées d'études sur les pollutions marines en Méditerranée, Workshop on Pollution of the Mediterranean, Cannes, France, 24 December 1982, 183-189, 1983.

Chazottes, V., Le Campion-Alsumard, T., and Peyrot-Clausades, M.: Bioerosion rates on coral reefs: interactions between macroborers, microborers and grazers (Moorea, French Polynesia), Palaeogeogr. Palaeocl. Palaeoecol., 113, 189-198, 1995.

Chazottes, V., Le Campion-Alsumard, T., Peyrot-Clausade, M., and Cuet, P.: The effects of eutrophication-related alterations to coral reef communities on agents and rates of bioerosion (Reunion Island, Indian Ocean), Coral Reefs, 21, 375-390, 2002.

Cherchi, A., Da Pelo, S., Ibba, A., Mana, D., Buosi, C., and Floris, N.: Benthic foraminifera response and geochemical characterization of the coastal environment surrounding the polluted industrial area of Portovesme (South-Western Sardinia, Italy), Mar. Pollut. Bull., 59, 281-296, 2009.

Cidu, R.: Trace elements Li, Be, B, Al, V, Cr, Co, Ni, Se, Sr, Ag, $\mathrm{Sn}, \mathrm{Sb}, \mathrm{Ba}$ and Tl, in: Handbook of Water Analysis, edited by: Nollet, L. M. L. and Dekker, M., Inc., 459-482, 1999.

Coccioni, R., Marsili, A., and Venturati, A.: Foraminiferi e stress ambientale, in: Verso la Gestione integrata della Costa del Monte San Bartolo: Risultati di un Progetto Pilota, edited by: Coccioni, R., Quaderni del Centro di Geobiologia dell’Università degli Studi di Urbino 1, 99-118, 2003.

Coccioni, R., Frontalini, F., Marsili, A., and Troiani, F.: Foraminiferi bentonici e metalli in traccia: implicazioni ambientali, in: La dinamica Evolutiva della Fascia Costiera tra le foci dei Fiumi Foglia e Metauro: Verso la Gestione Integrata di una Costa di Elevato Pregio Ambientale, edited by: Coccioni, R., Quaderni del Centro di Geobiologia dell'Università degli Studi di Urbino 3, 57-92, 2005.

Crevison, H. and Hallock, P.: Anomalous features observed on tests of live archaiasine foraminifers from the Florida Keys, USA, J. Foraminifer. Res., 37, 223-233, 2007.

Danzer, K. and Currie, L. A.: Guidelines for calibration in analytical chemistry, Pure Appl. Chem., 70, 993-1014, 1998.

Debenay, J. P. and Guiral, D.: Mangrove swamp foraminifera, indicators of sea level or paleoclimate cf., Revue de Paléobiologie, 2, 567-574, 2006.

Debenay, J. P., Guillou, J. J., Redois, F., and Geslin, E.: Distribution trends of foraminiferal assemblages in paralic environments: a base for using foraminifera as early warning indicators of anthropic stress, in: Environmental Micropaleontology, edited by: Martin, R., Kluwer Academic/Plenum Publishing Corporation, 39-67, 2000a.

Debenay, J. P, Guillou, J. J., Geslin, E., and Lesourd, M.: Crystallization of calcite in foraminiferal tests, Micropaleontology, 46, 87-94, 2000b.

Debenay, J. P., Geslin, E., Eichler, B. B., Duleba, W., Sylvestre, F., and Eichler, P.: Foraminiferal assemblages in a hypersaline 
lagoon Araruama (RJ) Brazil, J. Foraminifer. Res., 31, 133-151, 2001.

Debenay, J. P., Millet, B., and Angelidis, M. O.: Relationships between foraminiferal assemblages and hydrodynamics in the Gulf of Kalloni, Greece, J. Foraminifer. Res., 35, 327-343, 2005.

Denoyelle, M., Geslin, E., Jorissen, F. J., Cazes, L., and Galgani, F.: Innovative use of foraminifera in ecotoxicology: A marine chronic bioassay for testing potential toxicity of drilling muds, Ecol. Indic., 12, 17-25, 2012.

Di Gregorio, F., Federici, P. R., Fierro, G., and Ginesu, S.: Atlante delle spiagge della Sardegna, Foglio n. 232-233, Isola di S. Pietro-Carbonia, R.A.S, Cagliari, 1996.

Dickson, A. G. and Goyet, C. (Eds.): Handbook of methods for the analysis of the various parameters of the carbon dioxide system in sea water, Version 2, ORNL/CDIAC-74, 1-187, 1994.

Fatela, F. and Taborda, R.: Confidence limits of species proportion in microfossil assemblage, Mar. Micropaleontol., 45, 169-174, 2002.

Foster, W. J., Armynot du Châtelet, E., and Rogerson, M.: Testing benthic foraminiferal distributions as a contemporary quantitative approach to biomonitoring estuarine heavy metal pollution, Mar. Pollut. Bull., 64, 1039-1048, 2012.

Freiwald, A.: Bacteria-induced carbonate degradation: a taphonomic case, study of Cibicides lobatulus from a high-boreal carbonate setting, Palaios, 10, 337-346, 1995.

Frezza, V. and Carboni, M. G.: Distribution of recent foraminiferal assemblages near the Ombrone River mouth (Northern Tyrrhenian Sea, Italy), Revue de Micropaléontologie, 52, 43-66, 2009.

Frontalini, F. and Coccioni, R.: Benthic foraminifera as bioindicators of pollution: A review of Italian research over the last three decades, Revue de Micropaléontologie, 54, 115-127, 2011.

Frontalini, F., Buosi, C., Da Pelo, S., Coccioni, R., Cherchi, A., and Bucci, C.: Benthic foraminifera as bio-indicators of trace element pollution in the heavily contaminated Santa Gilla lagoon (Cagliari, Italy), Mar. Pollut. Bull., 58, 858-877, 2009.

Gazzetta Ufficiale della Repubblica Italiana: Piano di disinquinamento per il risanamento del territorio del Sulcis-Iglesiente, 190, 14 August 1993.

Ghirardelli, L. A.: Endolithic Microorganisms in Live and Dead Thalli of Coralline Red Algae (Corallinales, Rhodophyta) in the Northern Adriatic Sea, Acta Geologica Hispanica, 37, 53-60, 2002.

Glaub, I.: Mikrobohrspuren in ausgewählten Ablagerungsräumen des europäischen Jura und der Unterkreide (Klassifikation und Palökologie), Cour. For. Sekenbg., 174, 1-289, 1994.

Glaub, I.: Recent and sub-recent microborings from the upwelling area off Mauritania (West Africa) and their implications for palaeoecology, in: The Applications of Ichology to Palaeoenvironmental and Stratigraphic Analysis, edited by: Mc-Ilroy, D., Geolog. Soc. London, Spec. Publ., 228, 63-76, 2004.

Golubic, S. and Schneider, J.: Microbial endoliths as internal biofilms, in: Fossil and Recent biofilms, edited by: Krumbein, W. E., Dornieden, T., and Volkmann, M., Kluwer, Dordrecht, 249263, 2003.

Golubic, S., Brent, G., and Le Campion-Alsumard, T.: Scanning electron microscopy of endolithic algae and fungi using a multipurpose casting-embedding technique, Lethaia, 3, 203-209, 1970.
Golubic, S., Perkins, R. D., and Lukas, K. J.: Boring microorganisms and microborings in carbonate substrates, in: The Study of Trace Fossils, edited by: Frey, R. W., Springer-Verlag, New York., 229-259, 1975.

Golubic, S., Friedmann, I., and Schneider, J.: The lithobiontic ecological niche, with special reference to microorganisms, Sediment. Geol., 51, 475-478, 1981.

Golubic, S., Campbell, S. E, and Spaeth, C.: Kunstharzangüsse fossilifer Mikroben-Bohrgänge, Präparator, 29, 197-200, 1983.

Golubic, S., Campbell, S. E, Drobne, K., Cameron, B., Balsam, W. L., Cimerman, F., and Dubois, L.: Microbial endoliths: a benthic overprint in the sedimentary record, and a paleobathymetric cross-reference with foraminifera, J. Paleontol., 58, 351-361, 1984.

Hallock, P.: Symbiont-bearing foraminifera:harbingers of global change cf., Micropaleontology, 46, 95-104, 2000a.

Hallock, P.: Larger foraminifera as indicators of coral-reef vitality, in: Environmental Micropaleontology, edited by: Martin, R., Kluwer Academic/Plenum Publishing Corporation, 121-150, $2000 b$.

Hallock, P.: Global change and modern coral reefs: New opportunities to understand shallow-water carbonate depositional processes, Sediment. Geol., 175, 19-33, 2005.

Hansen, H. J.: Shell construction in modern calcareous Foraminifera, in: Modern Foraminifera, edited by: Sen Gupta, B. K., Springer, New York, 57-70, 1999.

Hansen, H. J. and Reiss, Z.: Electron microscopy of Rotaliacean wall structures, B. Geol. Soc. Denmark, 20, 329-346, 1971.

Hemleben, C., Anderson, O. R., Berthold, W., and Spindler, M.: Calcification and chamber formation in Foraminifera - a brief overview, in: Biomineralization in Lower Plants and Animals, edited by: Leadbeater, B. S. C. and Riding, R., Oxford, England, Clarendon Press, 237-249, 1986.

Hottinger, L.: Comparative anatomy of elementary shell structures in selected larger foraminifera, in: Foraminifera, edited by: Hedley, R. H. and Adams, C. G., New York, Academic Press, 3, 203 266, 1978.

Hottinger, L.: Functional morphology of benthic foraminiferal shells, envelopes of cells beyond measure, Micropaleontology, 46, 57-86, 2000.

Jarvis, I.: Sample preparation for ICPMS, in: Handbook of Inductively Coupled Plasma Mass Spectrometry, edited by: Jarvis, K. E., Gray, A. L., and Houk, R. S., Blackie Academic and Professional, Glasgow, UK, 172-224, 1992.

Lea, D. W.: Trace elements in foraminiferal calcite, in: Modern foraminifera, edited by: Sen Gupta, B. K., Kluwer Academic Publishers, UK, 259-277, 1999.

Lea, D. W.: Elemental and isotopic proxies of past ocean temperatures, in: The Oceans and Marine Geochemistry, Treatise on geochemistry volume 6, edited by: Elderfield, H., Holland, H. D., and Turekian, K. K., Elsevier, Amsterdam, Heidelberg, 365-390, 2004.

Le Campion-Alsumard, T., Golubic, S. and Hutchings, P.: Microbial endoliths in skeletons of live and dead corals: Porites lobata (Mooréa, French Polynesia), Mar. Ecol.-Prog. Ser., 117, 149157, 1995.

Lopez, O., Zuddas, P., and Faivre, D.: Influence of temperature and seawater composition on calcite crystal growth mechanisms and kinetics: implications for $\mathrm{Mg}$ incorporation in calcite lattice, 
Geochim. Cosmochim. Acta, 73, 23370-23470, 2009.

Millero, F. J. and Scheiber, D. R.: Use of the ion pairing model to estimate activity coefficients of the ionic components of natural water, Am. J. Sci., 282, 1508-1540, 1982

Mojtahid, M., Zubkov, M. V., Hartmann, M., and Gooday, A. J.: Grazing of intertidal benthic foraminifera on bacteria: Assessment using pulse-chase radiotracing, J. Exp. Mar. Biol. Ecol., 399, 25-34, 2011.

Morse, J. W.: The kinetics of calcium carbonate dissolution and precipitation, in: Carbonates: Mineralogy and Chemistry, edited by: Reeder, R. J., Mineralogical Society of America, Washington D.C., 11, 227-264, 1983.

Morse, J. W., Arvidson, R. S., and Lüttge, A.: Calcium carbonate formation and dissolution, Chem. Rev., 107, 342-381, 2007.

Munsel, D., Kramar, U., Dissard, D., Nehrke, G., Berner, Z., Bijma, J., Reichart, G.-J., and Neumann, T.: Heavy metal incorporation in foraminiferal calcite: results from multi-element enrichment culture experiments with Ammonia tepida, Biogeosciences, 7, 2339-2350, doi:10.5194/bg-7-2339-2010, 2010.

Murray, J. W.: Comparative studies of living and dead benthic foraminiferal distributions, in: Foraminifera, edited by: Hedley, R. H. and Adams, C. G., Academic Press, London, 45-110, 1976.

Murray, J. W. (Ed.): Ecology and Palaeoecology of Benthic Foraminifera, Longman Scientific and Technical, New York, 1426, 1991.

Nielsen, K. S. S., Nielsen, J. K., and Bromley, R. G.: Palaeoecological and ichnological significance of microborings in Quaternary foraminifera, Palaeontol. Electron., 6, 1-13, 2003.

Nordstrom, D. K.: Thermochemical redox equilibria of Zobell's solution, Geochim. Cosmochim. Acta, 41, 1835-1841, 1977.

Nordstrom, D. K: Hydrogeochemical processes governing the origin, transport and fate of major and trace elements from mine wastes and mineralized rock to surface waters, Appl. Geochem., 26, 1777-1791, 2011.

Peebles, M. W. and Lewis, R. D.: Differential infestation of shallowwater benthic foraminifera by microboring organisms: possible biases in preservation potential, Palaios, 3, 345-351, 1988.

Perkins, R. D. and Halsey, S. D.: Geologic significance of microboring fungi and algae in Carolina shelf sediments, J. Sediment. Petrol., 41, 843-853, 1971.

Perkins, R. D. and Tsentas, C. I.: Microbial infestations of carbonate substrates planted on the St Croix shelf, West Indies, Geol. Soc. Am. Bull., 87, 1616-1628, 1976.

Perry, C. T.: Grain susceptibility to the effects of microboring: implications for the preservation of skeletal carbonates, Sedimentology, 45, 39-51, 1998.

Radtke, G., Le Campion-Alsumard, T., and Golubic, S.: Microbial assemblage of the bioerosional "notch" along tropical limestone coasts, Algological Studies, 83, 469-482, 1996.

Ries, J. B., Cohen, A. L., and McCorkle, D. C.: Marine calcifiers exhibit mixed responses to $\mathrm{CO}_{2}$-induced ocean acidification, $\mathrm{Ge}$ ology, 37, 1131-1134, 2009.

Romano, E., Bergamin, L., Ausili, A., Pierfranceschi, G., Maggi, C., Sesta, G., and Gabellini, M.: The impact of the Bagnoli industrial site (Naples, Italy) on sea-bottom environment. Chemical and textural features of sediments and the related response of benthic foraminifera, Mar. Pollut. Bull., 59, 245-256, 2009.

Samir, A. M. and El-Din, A. B.: Benthic foraminiferal assemblages and morphological abnormalities as pollution proxies in two
Egyptian bays, Mar. Micropaleontol., 41, 193-237, 2001.

Schintu, M. and Degetto, S.: Sedimentary records of heavy metals in the industrial harbour of Portovesme, Sardinia (Italy), Sci. Total Environ., 241, 129-141, 1999.

Schneider, J. and Torunski, H.: Biokarst on limestone coasts, morphogenesis and sediment production, Mar. Ecol., 4, 45-63, 1983.

Scott, D. B. and Medioli, F. S.: Quantitative studies of marsh foraminiferal distribution in Nova Scotia and comparison with those in other parts of the world: implications for sea level studies, Cushman Foundation for Foraminiferal Research, Special Publication, 17, 58 pp., 1980.

Shroba, C. S.: Taphonomic features of benthic foraminifera in a temperate setting: experimental and field observations on the role of abrasion, solution and microboring in the destruction of foraminiferal tests, Palaios, 8, 250-266, 1993.

Succi, M. C., Romano, E., Bergamin, L., Celia Magno, M., and Carboni M. G.: Morphological abnormalities in benthic foraminifera from the highly anthropized Orbetello Lagoon (Tuscany, Italy), in: Forams 2010, International Symposium on Foraminifera, Bonn, 5-10, September 2010.

Toler, S. K., Hallock, P., and Schijf, J.: $\mathrm{Mg} / \mathrm{Ca}$ ratios in stressed foraminifera, Amphistegina gibbosa, from the Florida Keys, Mar. Micropaleontol., 43, 199-206, 2001.

Towe, K. and Cifelli, R.: Wall ultrastructure in the calcareous foraminifera: crystallographic aspects and a model for calcification, J. Paleontol., 41, 742-762, 1967.

Toyofuku, T. and Kitazato, H.: Micromapping of $\mathrm{Mg} / \mathrm{Ca}$ values in cultured specimens of the high-magnesium benthic foraminifera, Geochem. Geophys. Geosyst., 6, Q11P05, doi:10.1029/2005GC000961, 2005.

Tribollet, A.: The boring microflora in modern coral reefs: a review of its roles, in: Current Developments in Bioerosion, edited by: Wisshak, M. and Tapanila, L., Springer-Verlag, BerlinHeiderlberg, 67-94, 2008.

Tribollet, A. and Golubic, S.: Cross-shelf differences in the pattern and pace of bioerosion of experimental carbonate substrates exposed for 3 years on the northern Great Barrier Reef, Australia, Coral Reefs, 24, 422-434, 2005.

Tribollet, A. and Payri, C.: Bioerosion of the coralline alga Hydrolithon onkodes by microborers in the coral reefs of Moorea, French Polynesia, Oceanol. Acta, 24, 329-342, 2001.

Tribollet, A., Godinot, C., Atkinson, M., and Langdon, C.: Effects of elevated $p \mathrm{CO}_{2}$ on dissolution of coral carbonates by microbial euendoliths, Global Biogeochem. Cy., 23, GB3008, doi:10.1029/2008GB003286, 2009.

Tudhope, A. W. and Risk, M. J.: Rate of dissolution of carbonate sediments by microboring organisms, Davies Reef, Australia, J. Sediment. Petrol., 55, 440-447, 1985.

Vogel, K., Gektidis, M., Golubic, S., Kiene, W. E., and Radtke, G.: Experimental studies on microbial bioerosion at Lee Stocking Island, Bahamas and One Tree Island, Great Barrier Reef, Australia: implications for paleoecological reconstructions, Lethaia, 33, 191-204, 2000.

Walton, W. R.: Techniques for recognition of living foraminifera. Contributions from the Cushman Foundation for Foraminiferal Research, 3, 56-90, 1952.

Wefer, G., Berger, W. H., Bijma, J., and Fischer, G.: Clues to ocean history: A brief overview of proxies, in: Use of proxies in paleoceanography, edited by: Fischer, G. and Wefer, G., Springer, 
Berlin, Heidelberg, New York, Barcelona, Hong Kong, London, Milan, Paris, Singapore, Tokyo, 1-68, 1999.

Wisshak, M., Gektidis, M., Freiwald, A., and Lundälv, T.: Bioerosion along a bathymetric gradient in cold-temperate setting (Kosterfjord, SW Sweden): an experimental study, Facies, 51, 93-117, 2005.

Wisshak, M., Seuss, B., and Nützel, A.: Evolutionary implications of an exceptionally preserved Carboniferous microboring assemblage in the Buckhorn Asphalt Lagerstätte (Oklahoma, USA), in: Current Developments in Bioerosion, edited by: Wisshak, M. and Tapanila, L., Springer-Verlag, Berlin-Heiderlberg, 21-54, 2008.

Yanko, V., Kronfeld, J., and Flexer, A.: Response of benthic foraminifera to various pollution sources: implications for pollution monitoring, J. Foraminifer. Res., 24, 1-17, 1994.
Yanko, V., Ahmad, M. G., and Kaminski, M.: Morphological deformities of benthic foraminiferal tests in response to pollution by heavy metals: implications for pollution monitoring, J. Foraminifer. Res., 28, 177-200, 1998.

Yanko, V., Arnold, A. J., and Parker, W. C.: Effects of marine pollution on benthic foraminifera, in: Modern Foraminifera, edited by: Sen Gupta, B. K., Kluwer Academic Publisher, Dordrecht, 217-235, 1999.

Zhang, Y. and Golubic, S.: Endolithic microfossils (Cyanophyta) from early Proterozoic stromatolites, Hebei, China, Acta Micropaleont. Sin., 4, 1-12, 1987. 